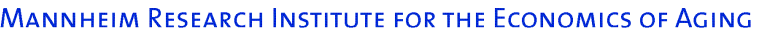

\title{
Sick LeAVE AND THE COMPOSITION OF WORK
}

TEAMS

Matthias Weiss

149-2007

○ $\boldsymbol{m e a - M a n n h e i m ~ R e s e a r c h ~ I n s t i t u t e ~ f o r ~ t h e ~ E c o n o m i c s ~ o f ~ A g i n g ~}$

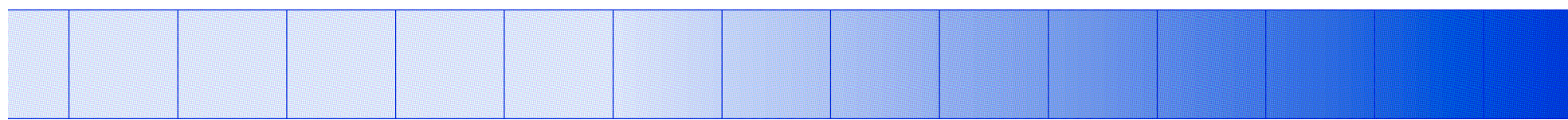

L13, 17_D-68131 Mannheim_Phone +49 621 181-2773/1862_Fax +49 621 181-1863_www.mea.uni-mannheim.de 


\title{
Sick Leave and the Composition of Work Teams*
}

\author{
Matthias Weiss ${ }^{\dagger}$
}

October 24, 2008

\begin{abstract}
In this paper, I analyse the relation between workers' sick leave and the composition of their work teams with respect to age, job tenure, education, and nationality.

The probability of sick leave of workers in work teams is shown to be lower if their teammates are older, have shorter job tenure, are less educated, female and of same nationality. In particular, the difference between a worker's age and the average age of her teammates explains a large part of the well-known positive correlation between age and sick days. In fact, for workers older than 44 years, individual age does not have any significant effect on sick days if the difference between individual age and average team age is held constant. This age difference can be controlled by the management. If older workers have more sick days only if they work in teams with younger workers, it might optimal to form age-homogeneous work teams.
\end{abstract}

JEL codes: J14, I10, M54

Keywords: Absenteeism, Teamwork, Age-Diverse Work Teams

\section{Introduction}

As the large cohort of babyboomers becomes older, the age composition of workers changes dramatically. By 2010 (respectively 2020), the largest age group in the workforce will be the fifty-year olds (respectively fiftyeight-year olds). ${ }^{1}$ This evolution in mind, it is important to better understand the relation between workers' age and their productivity. Sick leave is an important detriment to productivity: A worker's productivity equals zero whenever she calls in sick. Health deteriorates with age. Therefore, sick leave increases with age. A positive relationship between workers' age and their sick days is a common result in the literature. ${ }^{2}$ In this paper, I argue, that this simple correlation overstates the

${ }^{*}$ I am grateful to Axel Börsch-Supan, Ismail Düzgün, Melanie Lührmann, Dörte Naumann, and Martin Salm for very helpful comments. Simon Hilpert provided excellent research assistance. Funding by the State Baden-Württemberg and the Gesamtverband der Deutschen Versicherungswirtschaft is gratefully acknowledged.

${ }^{\dagger}$ MEA, Universität Mannheim, Germany, E-Mail: weiss@mea.uni-mannheim.de.

${ }^{1}$ These numbers refer to Germany. Similar numbers apply to other developed countries.

${ }^{2}$ In most studies of absenteeism, age is not the variable of central interest. Yet, whenever age is included as a control variable - which is usually the case - a positive relation between age and sick days is found. For a survey of the literature, see Alexanderson (1998). 
effect of age on sick leave.

The literature on absenteeism consists of two strands: One is concerned with the effects of individual characteristics of workers (sex, age, wage, education, health status, marital status, number of children) on their absenteeism. ${ }^{3}$ The other strand considers the role of the work environment (work conditions, sick pay arrangements, control mechanisms, firm size, contracts). ${ }^{4}$ What has - to the best of my knowledge - not been studied yet is the link between team composition and absenteeism. There is a literature in psychology that finds a negative relation between workers' job satisfaction and motivation to their absenteeism(see, eg, Steers and Rhodes (1978), Farrell and Stamm (1988), Scott and Taylor (1985), and Kohler and Mathieu (1993). Other studies, in turn, found that job satisfaction is affected by teammates' characteristics Spector (1997). ${ }^{5}$

In this paper, I explore a unique data set of workers in a truck assembly plant where I can identify workers who work together in a team on a daily basis. Thus, I am able to relate the probability of absence of a worker to her co-workers characteristics. Characteristics of the work team in this study include team size, average team age, and measures of diversity with respect to nationality, education, and age. For example, I can study the question whether older workers are absent more often if they work together with younger workers. This might be the case if workers conceive themselves as "older" and "sicker" if all their co-workers are much younger. The results confirm this hypothesis. It should be noted at this point that - even though "sickness" is reported as the reason for absenceother factors like motivation and pressure certainly have an effect (see Steers and Rhodes (1978)). The "decision" to call in sick is the result of a process that is influenced by all three: Health, motivation and pressure/control. If motivation and pressure/control are weak, "less sickness is needed" to actually call in sick. In addition, motivation (job satisfaction, etc.) and pressure can affect workers' health and thereby indirectly affect absenteeism.

\section{The Data}

I exploit a unique data set from an assembly plant of a German car manufacturer. At this plant, cars are assembled by work teams on a production line. The assembly line is split into 50 workplaces at which teams of 10 to 15 workers work together. I have information on the daily composition of these work teams on any work day in 2003 through 2005 and

\footnotetext{
${ }^{3}$ Economists as well as psychologists have contributed to this literature strand. See, eg, Hedges (1973), Leigh (1983), Paringer (1983), Eyal, Carel, and Goldsmith (1994), Bridges and Mumford (2001), Flabbi and Ichino (2001), Ichino and Moretti (2006), and the survey by Steers and Rhodes (1978)

${ }^{4}$ This literature strand consists mostly of economics papers. See, eg, Allen (1981b), Allen (1981a), Leigh (1981), Barmby, Orme, and Treble (1991), Barmby, Orme, and Treble (1995), Askildsen, Bratberg, and Nilsen (2000), Vahtera, Kivimäki, and Pentti (2001), Henrekson and Persson (2004), Ichino and Riphahn (2004), Andrén (2005), and Ichino and Riphahn (2005).

${ }^{5}$ Mathieu and Kohler (1990), Harrison and Shaffer (1994), and Martocchio (1994) study the role of a person's coworkers' absenteeism for her own absence behavior and find a positive relationship.
} 


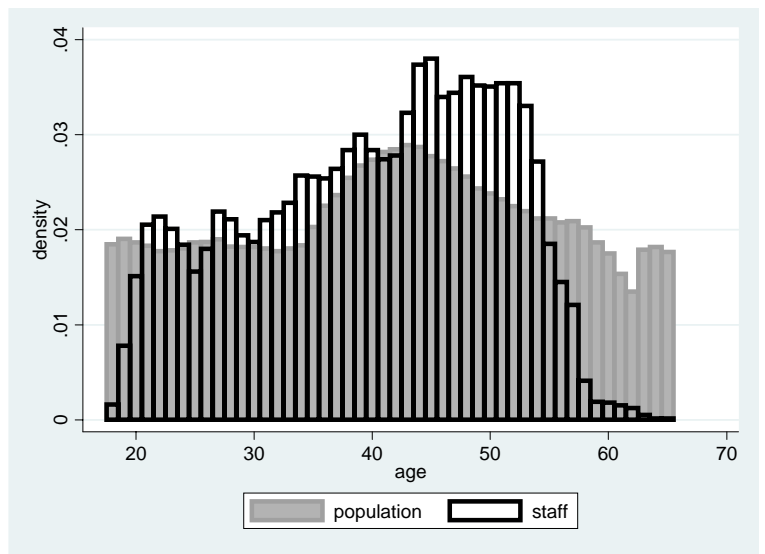

Figure 1: Age distribution in the plant (black) and in Germany (grey)

on personal characteristics of the workers such as age, sex, education, nationality, job tenure. In addition, the data contains information about the workload of each work team on each day and about whether or not a worker is in her regular team.

Age Composition The age composition in the plant is fairly representative for the German workforce in that workers older than 55 are rare. Figure 1 shows the age distribution in the plant (blue) in comparison to the age distribution of the whole population (orange). People younger than twenty are underrepresented because they are still in education or training. The share of workers aged 55 and over is low because many are already retired. Figure 2 shows the distribution of the average age of work teams.

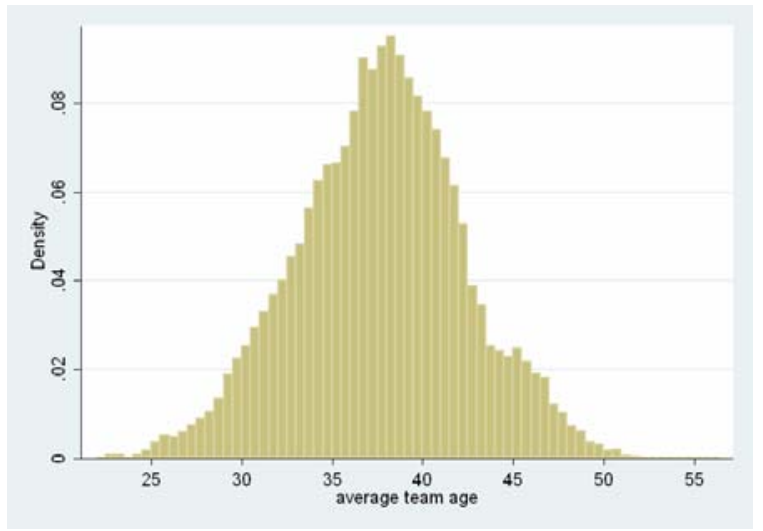

Figure 2: Distribution of average age of work teams.

Absence Rates The average rate of absence due to sickness is 5.5\%. ${ }^{6}$ There is variation over time and across workers as can be seen from Figure 3. Absence rates also vary quite

\footnotetext{
${ }^{6}$ In the remainder of the paper, I refer to absence due to sickness whenever I use the terms "absence", "sick leave", or "sick days".
} 

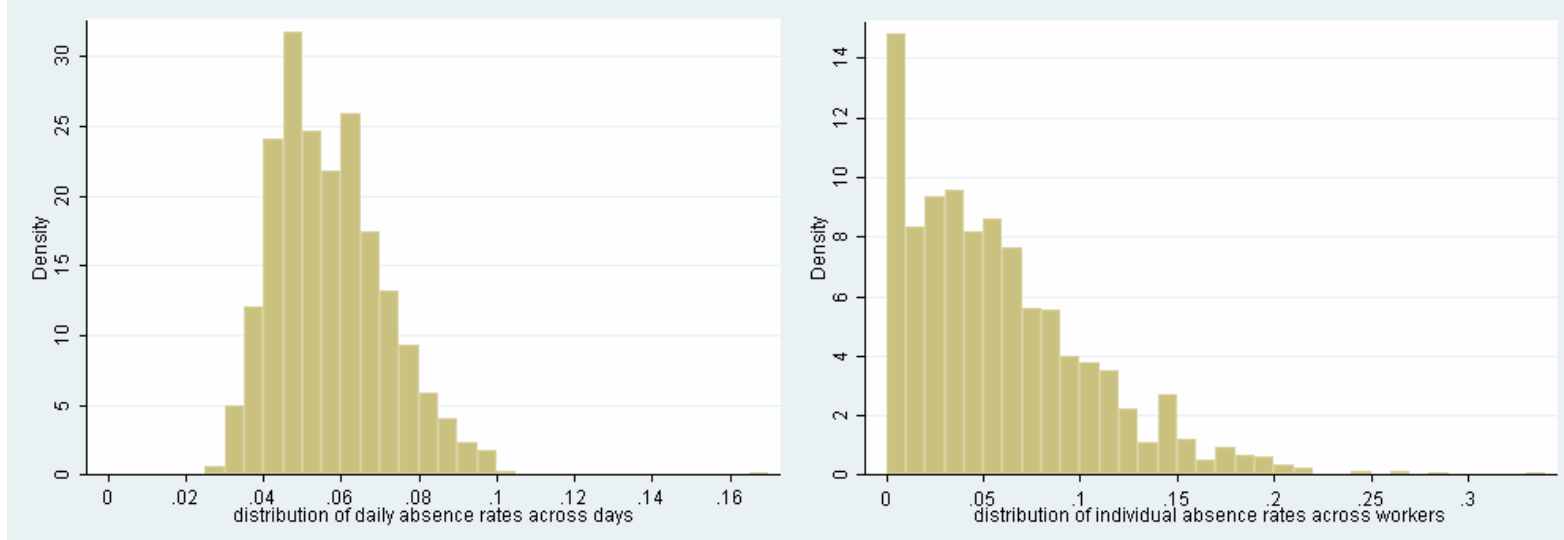

Figure 3: Distribution of absence rates due to sickness over time and across workers

substantially across age groups. On average, absence due to sickness increases with age (see the left panel of Figure 4). The next section will reveal whether this relation still
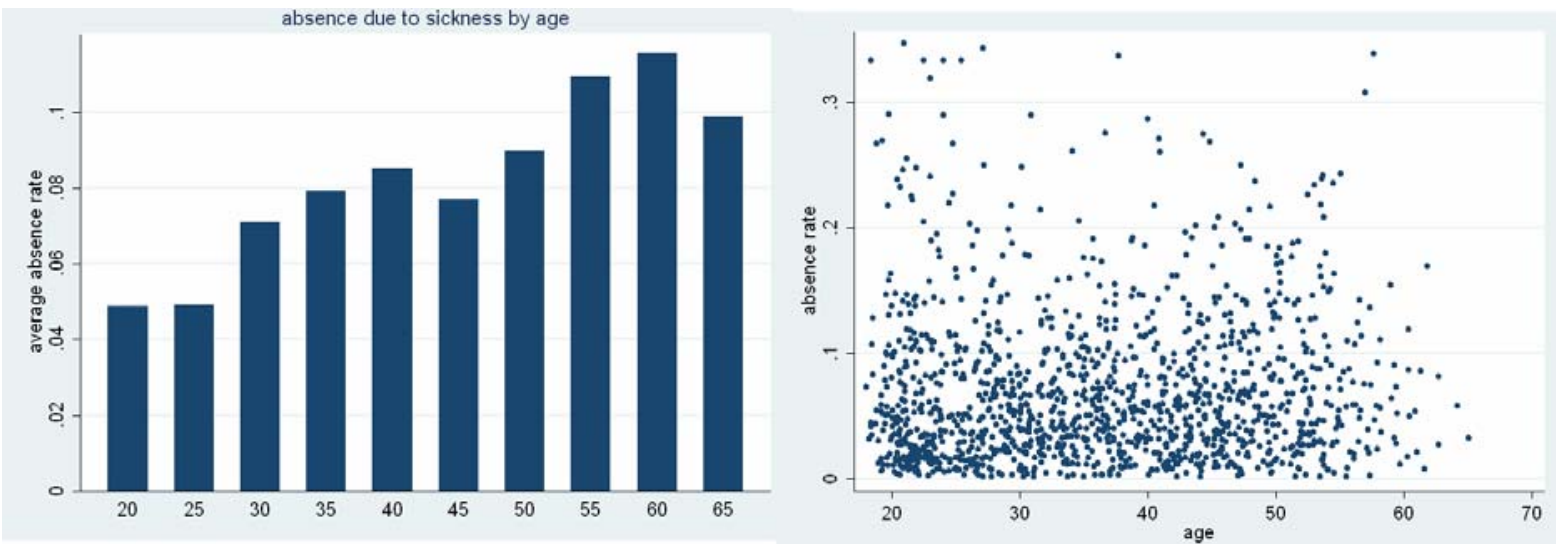

Figure 4: Average absence rates due to sickness by age group and individual absense rates vs. individual age

holds in a multivariate setting. The right panel of Figure 4 shows that absence rates also vary substantially within age groups.

Job Tenure In addition to age, I have information on workers' job tenure. Job tenure increases with age but the two variables are not perfectly correlated across workers as workers are hired at different ages. The distribution of individual job tenure in the plant is shown in the left panel of Figure 5. The spikes show hiring waves roughly every 5 to 10 years, the most recent having been just within the observation period (at job tenure $=0$ ). The distribution of average job tenure in work teams in the right panel of Figure 5 shows that at hiring waves, the new workers must have been spread evenly over existing work teams as the histogram in Figure 5 does not exhibit any comparable spikes. Figure 6 shows the relation between age and job tenure in the plant. For any individual worker, 

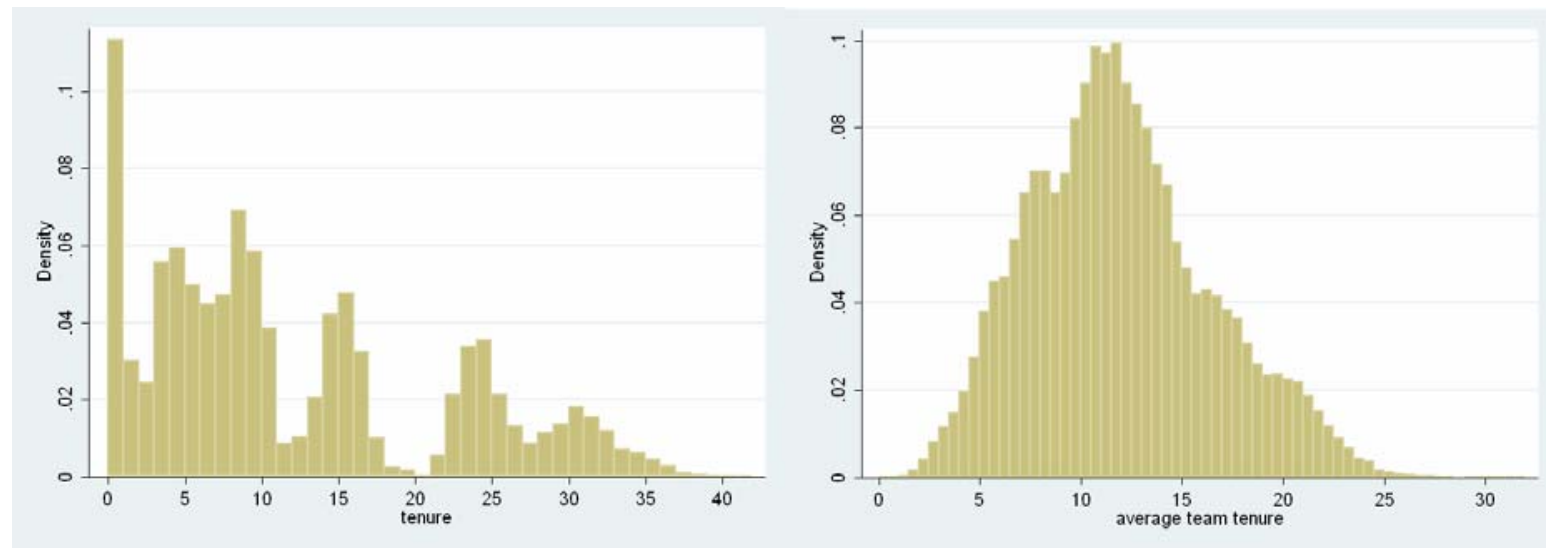

Figure 5: Distribution of job tenure in the plant: Individual (left panel) and work team average (right panel)

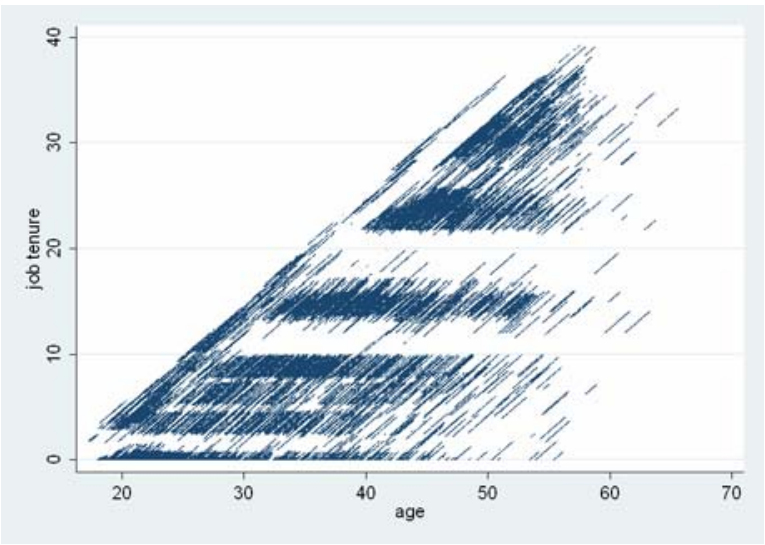

Figure 6: Scatter plot of job tenure (vertical axis) vs. age (horizontal axis).

age and job tenure are perfectly correlated over time, but as workers are hired at different ages, the overall correlation (over time and across workers) is "only" 0.79 .

Sex, Nationality, Education The share of women in the plant is 3.7\%. In $67 \%$ of all work teams, there are only men. In the other $33 \%$ of teams, women's share is about $11 \%$. The composition of the personnel with respect to nationality is given in the following table:

\begin{tabular}{ccccc}
\hline nationality & German & French & Turkish & other \\
\hline share & $69.9 \%$ & $24.5 \%$ & $3.8 \%$ & $4.7 \%$ \\
\hline
\end{tabular}

I also have information on the education of the workers. As a first go, I just calculated the total number of years of schooling for each worker. The distribution is shown in Figure 7. Most workers went to school for 9 years. Many of them complete an apprenticeship right afterwards. I count this as "schooling" as well, because in Germany, apprenticeships are very structured and $50 \%$ of their time, apprentices actually go to (vocational) school. 


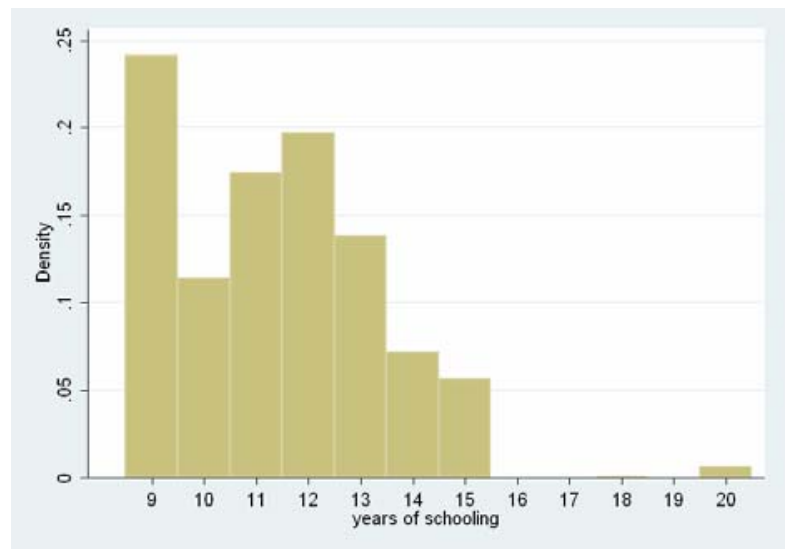

Figure 7: Distribution of schooling years

Work Load The production program and thereby the daily volume of work for every team varies over time. The required number of workers does not always exactly match the actual manning. I have daily information on actual volume of work (measured in workers) and actual manning for every day and every team. I use the percentage deviation of actual volume of work from actual manning as a measure of excess workload per worker. Figure 8 shows that the variation in excess workload is substantial.

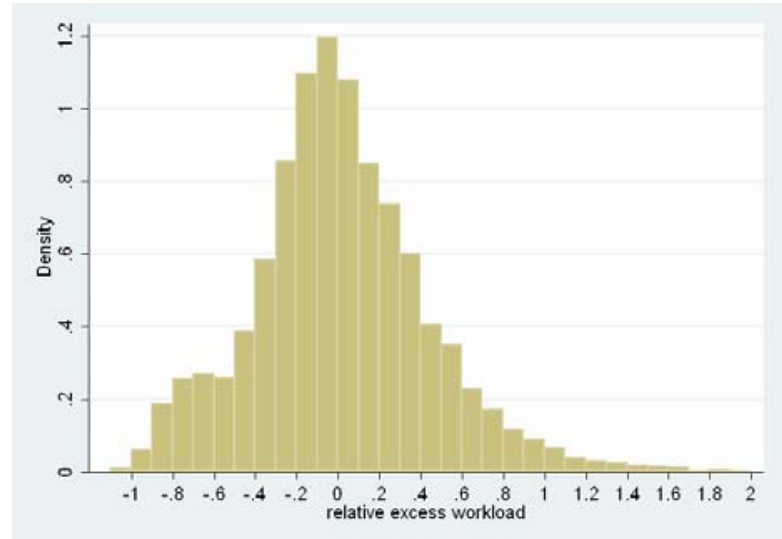

Figure 8: Distribution of excess work load (as a share of actual manning).

Team Size The size of work teams varies between 3 and 28 workers (see Figure 9). The appendix contains a table of descriptive statistics of all variables.

\section{Results}

I use day-to-day variation across 2271 workers during 2003 through 2005 (827 work days) to estimate the effects of individual and team characteristics on absence due to sickness. 


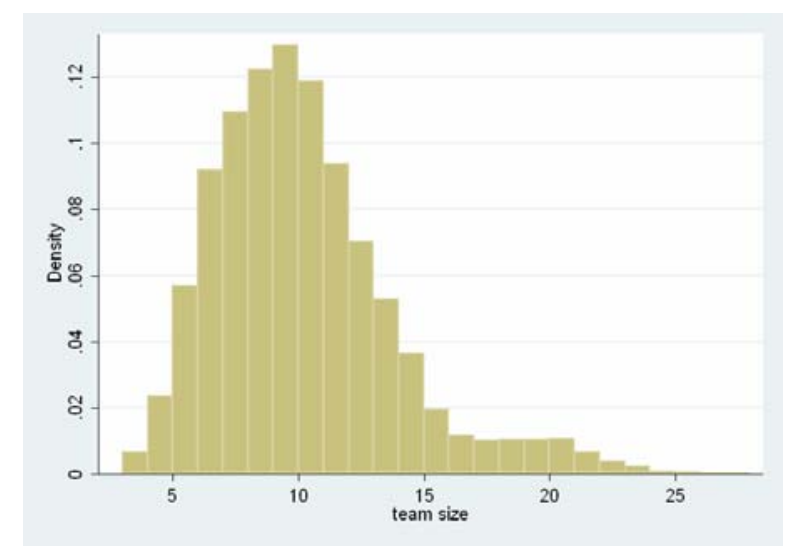

Figure 9: Distribution of team size in the plant.

I estimate a logit specification. The appendix contains additional information on some of the variables. Results are reported in Table 1. For many variables, I estimated polynomials and interactions so that the signs and the significance of the total marginal effects of these variables are not obvious from the coefficients in Table 1 . These total marginal effects and their significance are displayed in Table 2 .

Age Age has a significant effect on absenteeism up to the age of 44. For older workers, the marginal effect of age is insignificant. On the other hand, the difference between a worker's age and the average age in her team is highly significant especially for older workers. This means that elderly workers are absent more often, not because they are elderly per se, but because they are older than their teammates. Age diversity in teams thus leads to higher absence rates for older workers. One reason for this result might be that workers are more likely to feel stressed or sick if they perceive themselves as old and sick - also relative to their teammates. Controlling for the age of teammates is thus important. 


\section{Table 1: Regression Results}

\begin{tabular}{|c|c|c|c|c|c|}
\hline \multicolumn{6}{|c|}{ "Dependent variable: absence due to sickness (dummy, logit specification) } \\
\hline \multicolumn{3}{|c|}{ individual characteristics } & \multicolumn{3}{|c|}{ differences from team averages } \\
\hline age & 0.0718 & $(0.000)$ & age difference & 0.233 & $(0.000)$ \\
\hline age $^{2}$ & -0.000539 & $(0.000)$ & $(\text { age difference })^{2}$ & 0.00621 & $(0.000)$ \\
\hline tenure & 0.00850 & $(0.136)$ & tenure difference & -0.0100 & $(0.016)$ \\
\hline tenure $^{2}$ & 0.000209 & $(0.157)$ & $(\text { tenure difference })^{2}$ & -0.002471 & $(0.002)$ \\
\hline schooling & 0.219 & $(0.004)$ & schooling difference & -0.0641 & $(0.000)$ \\
\hline schooling $^{2}$ & -0.00619 & $(0.053)$ & $(\text { schooling difference) })^{2}$ & 0.00993 & $(0.005)$ \\
\hline schooling $\cdot$ age & -0.000740 & $(0.056)$ & & & \\
\hline female & -1.58 & $(0.000)$ & female "difference" & 1.03 & $(0.000)$ \\
\hline female $\cdot$ age & 0.00876 & $(0.011)$ & $(\text { female "difference" })^{2}$ & 0.278 & $(0.416)$ \\
\hline external & -0.572 & $(0.000)$ & external "difference" & -1.25 & $(0.000)$ \\
\hline external $\cdot$ age & 0.0104 & $(0.009)$ & $(\text { external "difference") })^{2}$ & 2.39 & $(0.000)$ \\
\hline early shift & 0.105 & $(0.209)$ & & & \\
\hline$($ early shift $) \cdot$ age & 0.00115 & $(0.585)$ & \multicolumn{3}{|c|}{ team characteristics } \\
\hline time trend & -0.000257 & $(0.000)$ & excess workload & 0.826 & $(0.000)$ \\
\hline tuesday & 0.225 & $(0.000)$ & $(\text { excess workload })^{2}$ & -0.743 & $(0.001)$ \\
\hline wednesday & 0.308 & $(0.000)$ & $($ excess workload $) \cdot$ age & -0.00541 & $(0.004)$ \\
\hline thursday & 0.333 & $(0.000)$ & team size & -0.0266 & $(0.007)$ \\
\hline friday & 0.380 & $(0.000)$ & $($ team size $) \cdot$ age & 0.00113 & $(0.000)$ \\
\hline \multirow[t]{2}{*}{ constant } & -2.23 & $(0.000)$ & share of workers with same nat. & -2.39 & $(0.000)$ \\
\hline & & & (same nationality) $\cdot$ age & 0.00346 & $(0.151)$ \\
\hline pseudo $R^{2}$ & 0.022 & & & & \\
\hline \multicolumn{6}{|c|}{ \# observations: 370,942 , unbalanced panel of 2271 workers in 100 teams on 827 days } \\
\hline \multicolumn{6}{|c|}{$\begin{array}{l}\text { Reference category for week day dummies: monday. All variables in the right column and "external" } \\
\text { and early shift are averages over the past five days. } p \text {-values are in brackets. }\end{array}$} \\
\hline
\end{tabular}

Job Tenure For job tenure, I find opposing effects: Longer individual job tenure leads to increasingly more sick days. This result conforms with the literature. Explanations are (i) that job security increases with job tenure so that the pressure to show up at work declines and (ii) that over the years, the job at the assembly line becomes boring so that the motivation to show up at work declines. On the other hand, having longer job tenure than the teammates affects to probability of sick leave conversely. One interpretation is in line with the psychological literature on absenteeism: Workers with the longest job tenure in the team are most likely to have more responsibility and more say in daily decisions. Baumgartel and Sobol (1959) (for responsibility) and Nicholson, Wall, and Lischeron (1977) (for participation in decisions) show that these variables are negatively related to absenteeism. The effects of individual job tenure and of distance to team job 
tenure seem to offset each other more or less.

\section{Table 2: Total Marginal Effects}

\begin{tabular}{|c|c|c|c|c|c|}
\hline \multicolumn{6}{|c|}{ dependent variable: paid absence } \\
\hline \multicolumn{3}{|c|}{ individual age } & \multicolumn{3}{|c|}{ age difference from team average } \\
\hline at age 20 : & 0.0234 & $(0.002)$ & at age diff. -20 : & 0.0108 & $(0.027)$ \\
\hline at age 30 : & 0.0180 & $(0.007)$ & at age diff. -10 : & 0.0171 & $(0.000)$ \\
\hline at age 40 : & 0.0126 & $(0.027)$ & at age diff. 0 : & 0.0234 & $(0.000)$ \\
\hline at age 50: & 0.00721 & $(0.135)$ & at age diff. 10: & 0.0295 & $(0.000)$ \\
\hline at age 60 : & 0.00182 & $(0.661)$ & at age diff. 20: & 0.0357 & $(0.000)$ \\
\hline \multicolumn{3}{|c|}{ individual job tenure } & \multicolumn{3}{|c|}{ tenure difference from team average } \\
\hline at tenure 0 : & 0.00850 & $(0.136)$ & at tenure diff. -10 : & -0.00531 & $(0.239)$ \\
\hline at tenure 10: & 0.0106 & $(0.026)$ & at tenure diff. 0: & -0.0100 & $(0.016)$ \\
\hline at tenure 20: & 0.0126 & $(0.002)$ & at tenure diff. 10: & -0.0147 & $(0.001)$ \\
\hline at tenure 30: & 0.0148 & $(0.000)$ & at tenure diff. 20: & -0.0230 & $(0.000)$ \\
\hline \multicolumn{3}{|c|}{ individual years of schooling } & \multicolumn{3}{|c|}{ schooling difference from team average } \\
\hline at 9 years: & 0.135 & $(0.003)$ & at schooling diff -2 : & -0.0839 & $(0.000)$ \\
\hline at 12 years: & 0.117 & $(0.002)$ & at schooling diff 0 : & -0.0641 & $(0.000)$ \\
\hline at 15 years: & 0.0983 & $(0.000)$ & at schooling diff 2 : & -0.0442 & $(0.004)$ \\
\hline at age 20: & 0.130 & $(0.001)$ & & & \\
\hline at age 30 : & 0.123 & $(0.001)$ & & & \\
\hline at age 40: & 0.115 & $(0.002)$ & & & \\
\hline at age 50: & 0.108 & $(0.000)$ & & & \\
\hline at age 60 : & -0.0715 & $(0.000)$ & & & \\
\hline \multicolumn{3}{|c|}{ sex $($ female $=1)$} & \multicolumn{3}{|c|}{ (female dummy) - (female share in team) } \\
\hline at age 20: & -1.29 & $(0.000)$ & at diff. $=-1$ : & 0.753 & $(0.032)$ \\
\hline at age 30: & -1.14 & $(0.000)$ & at diff. $=-0.5:$ & 0.892 & $(0.000)$ \\
\hline at age 40: & -1.00 & $(0.000)$ & at diff. $=0$ : & 1.03 & $(0.000)$ \\
\hline at age 50: & -0.856 & $(0.001)$ & at diff. $=0.5:$ & 1.17 & $(0.000)$ \\
\hline at age 60 : & -0.711 & $(0.006)$ & at diff. $=1$ : & 1.31 & $(0.001)$ \\
\hline \multicolumn{3}{|c|}{ external } & \multicolumn{3}{|c|}{ (external dummy) - (external share in team) } \\
\hline at age 20: & -0.779 & $(0.000)$ & at diff. $=-1$ : & -3.64 & $(0.000)$ \\
\hline at age 30: & -0.882 & $(0.000)$ & at diff. $=-0.5:$ & -2.44 & $(0.000)$ \\
\hline at age 40: & -0.986 & $(0.000)$ & at diff. $=0$ : & -1.25 & $(0.000)$ \\
\hline at age 50: & -1.09 & $(0.000)$ & at diff. $=0.5:$ & -0.504 & $(0.459)$ \\
\hline at age 60 : & -1.19 & $(0.000)$ & at diff. $=1$ : & 1.15 & $(0.000)$ \\
\hline
\end{tabular}


Education Regarding education, similar effects can be found. Workers with higher education have more sick days. But they have fewer sick days, the worse is their teammates' education relative to their own. The adverse effect of schooling diminishes with age and reverses at age 56. For the more than fifty-six-year olds, higher education reduces the probability of calling in sick.

\begin{tabular}{|c|c|c|c|c|c|}
\hline \multicolumn{6}{|c|}{ Table 2: Total } \\
\hline dependent variable: paid & bsence & & & & \\
\hline \multicolumn{3}{|c|}{ excess workload } & \multicolumn{3}{|c|}{ team size } \\
\hline at excess workload $-50 \%$ : & 0.608 & $(0.000)$ & at age 20 : & -0.00488 & $(0.381)$ \\
\hline at excess workload 0: & 0.594 & $(0.000)$ & at age 30 : & 0.00666 & $(0.075)$ \\
\hline at excess workload $50 \%$ : & 0.542 & $(0.000)$ & at age 40 : & 0.0182 & $(0.000)$ \\
\hline at age 20 : & 0.664 & $(0.000)$ & at age 50: & 0.0297 & $(0.000)$ \\
\hline at age 30 : & 0.614 & $(0.000)$ & at age 60: & 0.0413 & $(0.000)$ \\
\hline at age 40: & 0.565 & $(0.000)$ & & & \\
\hline at age 50: & 0.515 & $(0.000)$ & \multicolumn{3}{|c|}{ share of workers with same nationality } \\
\hline at age 60 : & 0.465 & $(0.000)$ & at age 20 : & -0.169 & $(0.000)$ \\
\hline & & & at age 30 : & -0.135 & $(0.000)$ \\
\hline & & & at age 40: & -0.100 & $(0.000)$ \\
\hline & & & at age 50: & -0.0657 & $(0.071)$ \\
\hline & & & at age 60 : & -0.0311 & $(0.576)$ \\
\hline
\end{tabular}

Total effects calculated as linear combinations of coefficients from Table 1. All effects are calculated at sample means unless otherwise indicated. $p$-values are in brackets.

Sex Women are less likely to be sick. This effect diminishes with age, but remains significantly negative. In addition, I include a variable, that measures the relation between own sex and one's team's sex composition. I subtract from the individual female dummy the female share of the team. The positive coefficients imply that women have fewer sick days if the female share is higher and men also have fewer sick days if the female share is higher.

External Workers Each worker is assigned to one team as her "regular" team. Butdue to fluctuations in team composition as a result of sick leave or vacation or fluctuations in workload - workers work outside their regular team $6 \%$ of the time on average. Being external to the team reduces the probability of sick leave. This effect becomes stronger with increasing age. However, the share of externals in the team reduces sick days of "regular" workers and increases sick days of external workers.

Nationality Workers' nationality has no significant effect on sick leave (not reported in table). But whether or not team mates have the same nationality matters. I calculated 
for each worker $i$ for each day the share of teammates who have the same nationality as worker $i$. This variable is highly significant for younger workers: The higher the share of compatriots in the team over the past five days, the less likely is a worker to call in sick. This effect vanishes with age.

Workload, Team Size Further control variables include excess workload and team size. Excess workload has adverse effects on sick leave. Somewhat surprisingly, however, this effect diminishes with age. Older worker's ability to cope with excess workload seems to be better. Larger team size leads to more sick days. This result has also been found in other studies and is related to lower group cohesiveness, higher task specialization, and poorer communication in larger teams (Indik (1965) and Porter and Lawler (1965)). The effect seems to be larger for older workers.

\section{Conclusion}

This paper contributes to the literature on the determinants of sick leave. It explores a unique data set that has information on day-to-day variation in the composition of work teams. This variation is used to identify effects of differences between individual and team characteristics on individual's probability to call in sick.

In particular, the difference between a worker's age and the average age of her teammates explains a large part of the well-known positive correlation between age and sick days. In fact, for workers older than 44 years, individual age does not have any significant effect on sick days if the difference between individual age and average team age is held constant. This is important because this age difference can be controlled by the management. If older workers have more sick days only if they work in teams with younger workers, it might be optimal to form age-homogeneous work teams.

More generally, the probability of sick leave of workers in work teams is shown to be lower if their teammates are older, have shorter job tenure, are less educated, female, of same nationality, and external to the team. One possible uniform of these effects interpretation is that an individual's absenteeism is less severe, the more he feels superior to his teammates. In the environment of the assembly line, this feeling of "superiority" may be characterized by youth, long job tenure, higher education, male sex, and being in her/his regular team. The reason for this effect may be job satisfaction due to either well being/feeling comfortable in the work team and/or having more interesting tasks and jobs within the work team.

Despite a vast literature on absenteeism in disciplines as diverse as economics, managerial sciences, psychology, and medicine, the relation between co-workers' characteristics and sick leave has not been studied yet. This paper is a first step. I find highly significant effects of teammates' characteristics on a worker's probability to call in sick. More research in this direction is needed to better understand these effects. 


\section{References}

Alexanderson, K. (1998): "Sickness Absence: A Review of Performed Studies with Focused on Levels of Exposures and Theories Utilized," Scandinavian Journal of Social Medicine, 26(4), 241 - 249.

Allen, S. G. (1981a): "Compensation, Safety, and Absenteeism: Evidence from the Paper Industry," Industrial and Labor Relations Review, 34(2), 207 - 218.

— (1981b): "An Empirical Model of Work Attendance," The Review of Economics and Statistics, 63(1), $77-87$.

Andrén, D. (2005): "Never on a Sunday: Economic Incentives and Sick Leave in Sweden," Applied Economics, 37(3), 327 - 338.

Askildsen, J. E., E. Bratberg, and Ø. A. Nilsen (2000): "Sickness Absence over the Business Cycle," Working Paper 4-2000, Department of Economics, University of Bergen.

Barmby, T. A., C. D. Orme, and J. G. Treble (1991): "Worker Absenteeism: An Analysis Using Microdata," The Economic Journal, 101(405), 214 - 229.

— (1995): "Worker Absence Histories: A Panel Data Study," Labour Economics, $2(1), 53-65$.

Baumgartel, H., and R. Sobol (1959): "Background and Organizational Factors in Absenteeism," Personnel Psychology, 12, 431 - 443.

Bridges, S., And K. Mumford (2001): "Absenteeism in the UK: A Comparison Across Genders," The Manchester School, 69(3), 276 - 284.

Eyal, A., R. S. Carel, and J. R. Goldsmith (1994): "Factors Affecting Long-Term Sick Leave in an Industrial Population," International Archives of Occupational and Environmental Health, 66(4), 279 - 282.

Farrell, D., and C. L. Stamm (1988): "Meta-Analysis of the Correlates of Employee Absence," Human Relations, 41(3), 221 - 227.

Flabbi, L., And A. Ichino (2001): "Productivity, Seniority and Wages: New Evidence from Personnel Data," Labour Economics, 8(3), 359 - 387.

Harrison, D. A., and M. A. Shaffer (1994): "Comparative Examinations of SelfReports and Perceived Absenteeism Norms: Wading Through Lake Woebegon," Journal of Applied Psychology, 79(2), 240 - 251.

Hedges, J. N. (1973): "Absence from Work-a Look at some National Data," Monthly Labor Review, 96(7), $24-30$. 
Henrekson, M., and M. Persson (2004): "The Effects on Sick Leave of Changes in the Sickness Insurance System," Journal of Labor Economics, 22(1), 87 - 113.

Ichino, A., And E. Moretti (2006): "Biological Gender Di Erences, Absenteeism and the Earning Gap," mimeo, University of Bologna http://www2.dse.unibo.it/ichino/cycle28.pdf.

Ichino, A., and R. Riphahn (2004): "Absenteeism and Employment Protection: Three Case Studies," Swedish Economic Policy Journal, 11(1), 95 - 114.

(2005): "The Effect of Employment Protection on Worker Effort - A Comparison of Absenteeism During and After Probation," Journal of the European Economic Association, 3(1), 120 - 143.

Indik, B. P. (1965): "Organization Size and Member Participation," Human Relations, $18,339-350$.

Kohler, S. S., and J. E. Mathieu (1993): "Individual Characteristics, Work Perceptions, and Affective Reactions Influences on Differentiated Absence Criteria," Journal of Organizational Behavior, 14(6), 515 - 530.

Leigh, J. P. (1981): "The The Effects of Union Membership on Absence from Work Due to Illness," Journal of Labor Research, 2(2), 329 - 336.

(1983): "Sex Differences in Absenteeism," Industrial Relations, 22(3), 349 - 361.

Martocchio, J. J. (1994): "The Effects of Absence Culture on Individual Absence," Human Relations, 47(3), $243-262$.

Mathieu, J. E., and S. S. Kohler (1990): "A Cross-Level Examination of Group Absence Influences on Individual Absence," Journal of Applied Psychology, 75(2), 217 -220 .

Nicholson, N., T. Wall, and J. Lischeron (1977): "The Predictability of Absence and Propensity to Leave from Employees' Job Satisfaction and Attitudes Toward Influence in Decision Making," Human Relations, 30, 499 - 514.

Paringer, L. (1983): "Women and Absenteeism: Health or Economics," American Economic Review, 73(2), 123 - 127.

Porter, L. W., and E. E. Lawler (1965): "Properties of Organization Structure in Relation to Job Attitudes and Job Behavior," Psychological Bulletin, 64, 23 - 51.

Scott, K., and G. S. Taylor (1985): "An Examination of Conflicting Findings on the Relationship Between Job Satifsfaction and Absenteeism: A Meta-Analysis," Academy of Management Journal, 28(3), $599-612$. 
Spector, P. E. (1997): Job Satisfaction: Application, Assessment, Causes, and Consequences, Advanced Topics in Organizational Behavior. SAGE Publications, Thousand Oaks, CA, USA.

Steers, R. M., and S. R. Rhodes (1978): "Major Influences on Employee Attendance: A Process Model," Journal of Applied Psychology, 63(4), 391 - 407.

Vahtera, J., M. Kivimäki, and J. Pentti (2001): "The Role of Extended Weekends in Sickness Absenteeism," Occupational and Environmental Medicine, 58, 818 - 822.

\section{Appendix}

In this appendix, I give some more information on the data I use in this paper. Table 3 gives some descriptive statistics of all variables used.

Some of the variables deserve (or require) some more explanation. "paid absence" is a dummy that takes the value one whenever a person is absent due to sickness.

All mean variables are daily team averages.

All "difference"-variables are daily differences of individual characteristics from the respective team average. Figures 10, 11, and 12 show the distributions of these variables.

The correlations between individual characteristics and respective differences from team averages are quite high. Yet, there is sufficient variation to identify the effects of both seperately. Figures 13 and 14 show scatter plots for age and job tenure.

Another variable that needs some explanation is the variable "share of workers with same nationality". This variable measures for every worker $i$ on every day the share of workers who have the same nationality as worker $i$. The distribution of this variable is given in Figure 15. The left mode of the distribution refers to non-German workers for whom the share of compatriots is small. The right mode refers to German workers who always have many other Germans in their teams.

All variables except age, job tenure, schooling, sex, and weekdays are calculated as averages over the past five days. 
Table 3: Descriptive Statistics

\begin{tabular}{|c|c|c|c|c|c|}
\hline variable & mean & median & minimum & maximum & std. dev. \\
\hline paid absence (dummy) & 0.0556 & 0 & 0 & 1 & 0.229 \\
\hline age & 37.7 & 37.5 & 17.3 & 65.6 & 10.9 \\
\hline mean team age & 37.7 & 37.8 & 22.0 & 56.1 & 4.66 \\
\hline difference from mean age & 0 & -0.05 & -29.6 & 32.4 & 9.82 \\
\hline tenure & 12.0 & 9.05 & 0 & 41.7 & 9.74 \\
\hline mean team tenure in team & 12.0 & 11.6 & 0.242 & 32.0 & 4.54 \\
\hline tenure difference & 0 & -1.8 & -26.7 & 32.5 & 8.62 \\
\hline schooling years & 11.4 & 11.4 & 9 & 20 & 1.93 \\
\hline mean team schooling & 11.4 & 11.4 & 9 & 14.0 & 0.612 \\
\hline $\begin{array}{l}\text { difference from mean } \\
\text { schooling in team }\end{array}$ & 0 & -0.47 & -4.79 & 9.17 & 1.82 \\
\hline female (dummy) & 0.0367 & 0 & 0 & 1 & 0.188 \\
\hline female share & 0.367 & 0 & 0 & 0.667 & 0.059 \\
\hline "female difference" & 0 & 0 & -0.667 & 0.969 & 0.178 \\
\hline external (dummy) & 0.0623 & 0 & 0 & 1 & 0.242 \\
\hline share of externals & 0.0623 & 0 & 0 & 1 & 0.089 \\
\hline "external difference" & 0 & 0 & -0.889 & 0.966 & 0.225 \\
\hline early shift (dummy) & 0.326 & 0 & 0 & 1 & 0.469 \\
\hline excess workload & 0.0190 & -0.015 & 0.441 & -1.09 & 1.93 \\
\hline team size & 10.2 & 9.97 & 3 & 28 & 3.69 \\
\hline $\begin{array}{l}\text { share of workers with } \\
\text { same nationality }\end{array}$ & 0.553 & 0.711 & 0 & 1 & 0.323 \\
\hline
\end{tabular}

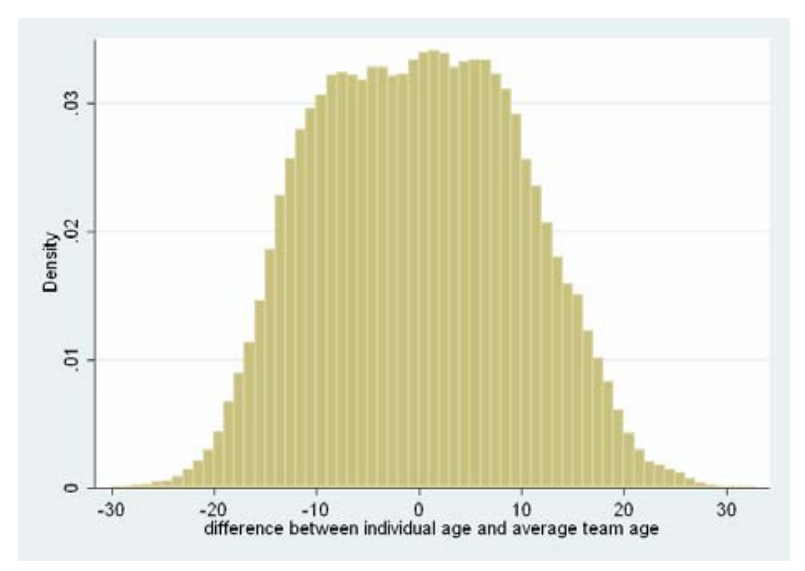

Figure 10: Distribution of the difference between a workers's age and the average age in her team 


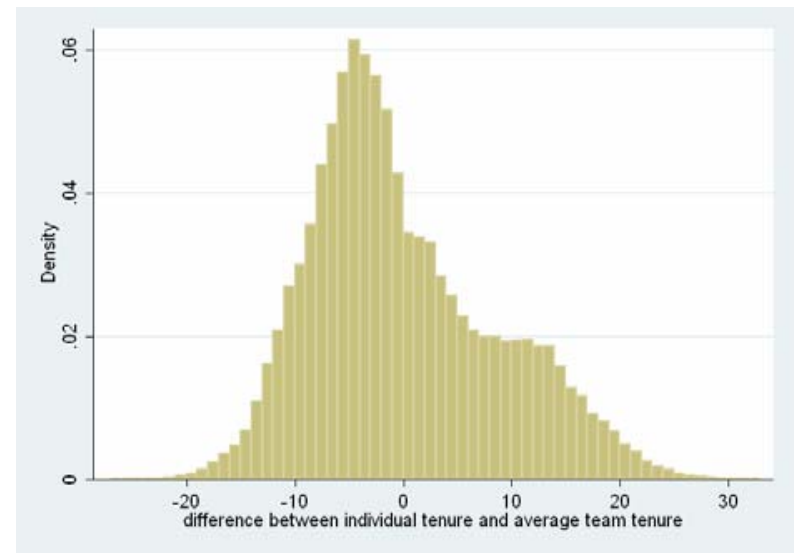

Figure 11: Distribution of the difference between a worker's job tenure and the average job tenure in her team

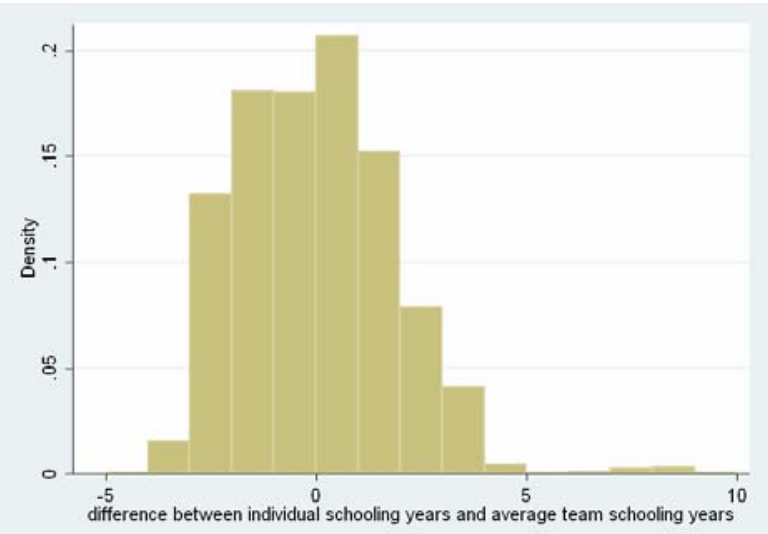

Figure 12: Distribution of the difference between a workers years of schooling and the average schooling years in her team

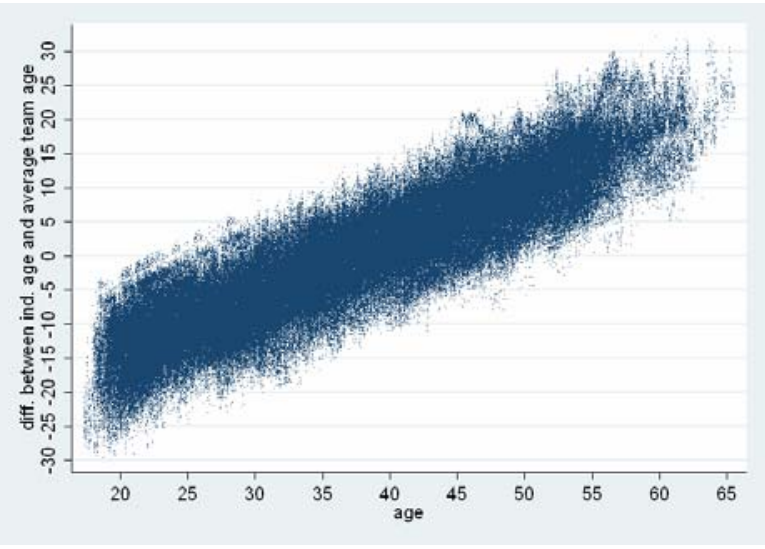

Figure 13: Individual age vs. the difference between individual age and average age in the work team 


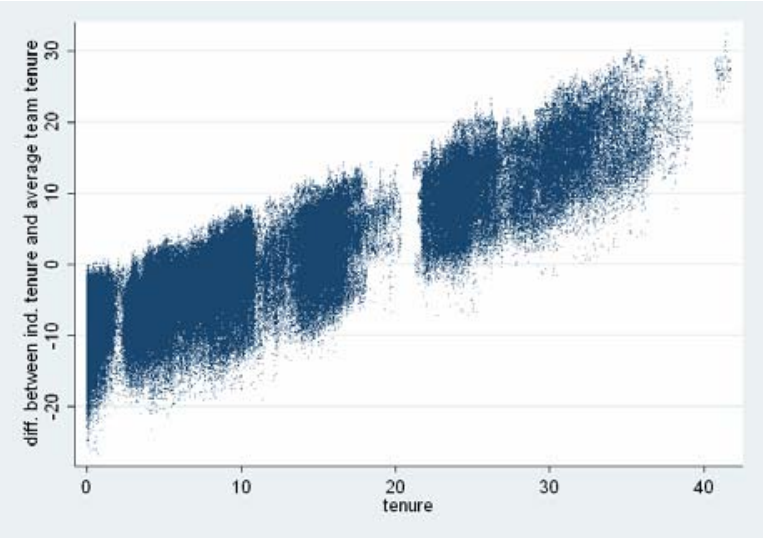

Figure 14: Individual job tenure vs. the difference between individual tenure the average job tenure in the work team

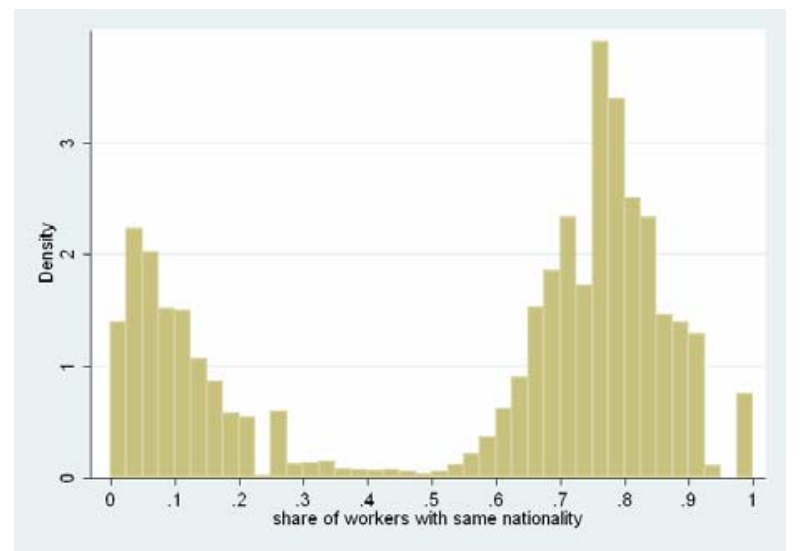

Figure 15: Distribution of the share of compatriots within the work team 


\section{Discussion Paper Series}

Mannheim Research Institute for the Economics of Aging Universität Mannheim

To order copies, please direct your request to the author of the title in question.

\begin{tabular}{|c|c|c|c|}
\hline Nr. & Autoren & Titel & Jahr \\
\hline $137-07$ & $\begin{array}{l}\text { Hendrik Jürges, } \\
\text { Mauricio Avendano, } \\
\text { Johan Mackenbach }\end{array}$ & $\begin{array}{l}\text { How comparable are different measures of self- } \\
\text { rated health? Evidence from five European } \\
\text { countries }\end{array}$ & 07 \\
\hline $138-07$ & $\begin{array}{l}\text { Hendrik Jürges, } \\
\text { Kerstion Schneider }\end{array}$ & $\begin{array}{l}\text { What can go wrong will go wrong: Birthday } \\
\text { effects and early tracking in the German school } \\
\text { system }\end{array}$ & 07 \\
\hline $139-07$ & Hendrik Jürges & $\begin{array}{l}\text { Does ill health affect savings intentions? } \\
\text { Evidence from SHARE }\end{array}$ & 07 \\
\hline $140-07$ & Hendrik Jürges & $\begin{array}{l}\text { Health inequalities by education, income, and } \\
\text { wealth: a comparison of } 11 \text { European countries } \\
\text { and the US }\end{array}$ & 07 \\
\hline $141-07$ & Hendrik Jürges & $\begin{array}{l}\text { Healthy minds in healthy bodies. An } \\
\text { international comparison of education-related } \\
\text { inequality in physical health among older adults }\end{array}$ & 07 \\
\hline $142-07$ & $\begin{array}{l}\text { Karsten Hank, } \\
\text { Stephanie Stuck }\end{array}$ & $\begin{array}{l}\text { Volunteer Work, Informal Help, and Care among } \\
\text { the 50+ in Europe: Further Evidence for 'Linked' } \\
\text { Productive Activities at Older Ages }\end{array}$ & 07 \\
\hline $143-07$ & Jürgen Maurer & $\begin{array}{l}\text { Assessing Horizontal Equity in Medication } \\
\text { Treatment Among Elderly Mexicans: Which } \\
\text { Socioeconomic Determinants Matter Most? }\end{array}$ & 07 \\
\hline $144-07$ & Jürgen Maurer & $\begin{array}{l}\text { Socioeconomic and Health Determinants of } \\
\text { Health Care Utilization Among Elderly } \\
\text { Europeans: A Semiparametric Assessment of } \\
\text { Equity, Intensity and Responsiveness for Ten } \\
\text { European Countries }\end{array}$ & 07 \\
\hline $145-07$ & Jürgen Maurer & $\begin{array}{l}\text { Modelling socioeconomic and health } \\
\text { determinants of health care use: A } \\
\text { semiparametric approach }\end{array}$ & 07 \\
\hline $146-07$ & $\begin{array}{l}\text { Jérome Adda, James } \\
\text { Banks, Hans-Martin } \\
\text { von Gaudecker }\end{array}$ & $\begin{array}{l}\text { The Impact of Income Shocks on Health: } \\
\text { Evidence from Cohort Data }\end{array}$ & 07 \\
\hline $147-07$ & $\begin{array}{l}\text { Klaus Jäger, } \\
\text { Wolfgang Kuhle }\end{array}$ & $\begin{array}{l}\text { The Optimum Growth Rate for Population } \\
\text { Reconsidered }\end{array}$ & 07 \\
\hline $148-07$ & $\begin{array}{l}\text { Axel Börsch-Supan, } \\
\text { Ismail Düzgün, } \\
\text { Matthias Weiss }\end{array}$ & $\begin{array}{l}\text { Age and Productivity in Work Teams: Evidence } \\
\text { from the Assembly Line }\end{array}$ & 07 \\
\hline $149-07$ & Matthias Weiss & Sick Leave and the Composition of Work Teams & 07 \\
\hline
\end{tabular}

